\title{
Effects of soybean and maize bran supplementation on carcass yield of local chickens under scavenging condition in mkwinda EPA, lilongwe, malawi
}

\begin{abstract}
An evaluation study on effect of supplementation on carcass yield of indigenous chicken was carried out at Mkwinda Extension Planning Area (E.P.A), Lilongwe. A total of thirty six chickens (18 cocks and 18 hens) were selected randomly from different clusters and were kept under scavenging system. The chickens were wing tagged for identification and allocated to three treatments [simple ration ( $89 \%$ maize bran, $10.75 \%$ soybean meal and $0.25 \%$ salt), maize bran and scavenging only as a control] under complete randomized design. The feedstuffs were analyzed for crude protein, crude fiber, ether extract, and dry matter before experiment. The supplementation was done in the morning and evening but age was not considered. The normal feathered chickens were selected for this experiment because they were mostly found in this EPA. Data collected included live weights, hot carcass dressed weight, cold carcass weight and visceral organs and parts. The results showed that simple ration significantly had highest live weights (1298g), hot carcass dressed weigh $\mathrm{t}(1098 \mathrm{~g})$, cold carcass weight $(899.68 \mathrm{~g})$ amongst all the treatments; scavenging live weights $(998.25 \mathrm{~g})$, hot dressed weight $(801.125 \mathrm{~g})$, cold carcass weight $(776.13 \mathrm{~g})$ and maize bran only live weights $(1100 \mathrm{~g})$, hot dressed weight $(1060.8 \mathrm{~g})$, cold carcass weight $(899.43 \mathrm{~g})$. The same trend was observed in weights of visceral organ parts. It was also observed that cocks had higher carcass and organ yield compared to hens in all the treatments. It is concluded that supplementing indigenous chickens under scavenging conditions with simple ration result in more carcass and organs yield. Therefore farmers should be supplementing indigenous chickens by formulating simple ration for better carcass yield in indigenous chickens.
\end{abstract}

Keywords: Carcass, indigenous chicken, lilongwe, treatment
Volume 3 Issue 2 - 2018

\author{
Hendrina Kassim, Jonathan Tanganyika \\ Lilongwe University of Agriculture and Natural Resources \\ (LUANAR), Malawi
}

Correspondence: Jonathan Tanganyika, Animal Science Department, Bunda campus, Lilongwe University of Agriculture and Natural Resources (LUANAR), PO Box 219, Lilongwe, Malawi, Tel 26599349 4774, Email jtanganyika@gmail.com

Received: February 15, 2018 | Published: March 28, 2018

\section{Introduction}

Village chickens are an important source of high-quality protein for the ever increasing rural and urban population and further provide the former with additional income, especially to the resource-poor communities. ${ }^{1}$ Village chickens in Africa are in general hardy, adaptive to rural environments, survive on little or no inputs and adjust to fluctuations in feed availability. ${ }^{2}$ Village chickens have a natural tendency to scavenge for their food resources. There has been a renewed enthusiasm in animal products that come from organic systems or the so called 'natural' systems. The recognized importance of village chickens in providing meat, cash income, socio-cultural values to rural people and their efficient scavenging system has led to increased research on the species during the past years. ${ }^{3}$

The scavenging feed resource base (SFRB) is defined as those feed resources available at farm level that consists of household refuse and all the materials available in the immediate environment that the scavenging birds can use as feed. ${ }^{1}$ The major feed sources for village chickens are worms, insects, seeds, green leaves and other plant materials available in the backyard. ${ }^{4}$ According to, ${ }^{5}$ grains, bran and household food leftovers are occasional sources of supplementary feed in purely free-ranging systems. The SFRB for village chickens varies immensely with season, climate and location. This has been reported in studies conducted in countries such as Ethiopia, Indonesia,
Sri Lanka and Tanzania. ${ }^{6,74}$ Although not clearly estimated, sufficient SFRB may be available to scavenging village chickens in the rainy season, but there is scarcity when it is dry, especially during the spring season when there are less crop residues and the plants are beginning to sprout. In the rainy season, insects/worms and green forage materials are in abundance whilst in the harvesting season there is a high supply of cereal grains and a low supply of green forages and insects/worms. ${ }^{4,1}$ However, there is little information regarding the carcass yield characteristics, of indigenous chickens. Therefore, this study will provide basic information on indigenous chicken in Malawi which then will assist farmers, researchers and policy makers for indigenous chicken's improvement programs in future.

\section{Materials and methods}

\section{Study area}

The study was conducted at Mkwinda EPA. Specifically Mkwinda, Kudowole and Kuchinani village. Each village had three clusters which were $1 \mathrm{~km}$ apart to prevent the mixed up of the chickens from one cluster to another. Each cluster had a maximum of 12 chickens where by all experimental chickens were wing tagged for identification. According to age they were adults. Chickens used for study were from the clusters which were bought by the Indigenous Chicken Improvement Program (InCIP). 


\section{Experimental animals and design}

Thirty six (36) chickens were randomly selected from the clusters. From each cluster at least four chickens were randomly selected based on their feeding system. These feeding systems were complete ration, maize bran and salt then control. The feed ration contains $89 \%$ maize bran $10.75 \%$ soybean and $0.25 \%$ salt. The chickens were starved overnight but water was provided for easy evisceration procedure and also to know their actual live weight, weighed and Slaughtered, de feathered manually and feathers were air dried to find their weight at Sakhula farm thereafter measurements were done using the electronic scale (Table 1).

Table I The way chickens were bought from the clusters (36 chickens)

\begin{tabular}{llll}
\hline Treatments & Hens & Cocks & Total \\
\hline Scavenging only & 5 & 7 & 12 \\
Maize bran only & 6 & 6 & 12 \\
Simple ration & 7 & 5 & 12 \\
& 18 & 18 & 36 \\
\hline
\end{tabular}

\section{Data collection}

The data collected was based on the live weight, sex by observation, live weight of the chickens; weight of feathers, Weight of empty gizzards, empty intestines, thighs, heads, breast muscles, wings, blood, liver, necks, hot dressed, back portion, drumstick wing, cold dressed weight, weight after bleeding, drumstick, empty crop.

\section{Data analysis}

The data collected was subjected to two ways ANOVA of the Statistical Packages for Social Science (SPSS) package considering effects of feeding system, Turkey's test, descriptive statistics, and estimated means was used to compare the means at the level of significance of $\mathrm{P}<0.05$ (Table 2).

Table 2 The approximate analysis

\begin{tabular}{lllll}
\hline Feed & CP\% & CF\% & EE\% & DM\% \\
\hline Simple ration & 14.42 & 66.36 & 15.83 & 4.08 \\
Control & - & - & - & - \\
Maize bran & 10.03 & 63.16 & 19.21 & 5.24 \\
\hline
\end{tabular}

\section{Statistical model}

$$
Y_{i j k}=\mu+M_{i}+S_{j}+(M S)_{i j}+e_{i j k}
$$

Where;

$\begin{array}{ll}Y_{i j k}= & \text { Observed carcass yield characteristics } \\ \mu= & \text { Overall mean of the observation } \\ M_{i}= & \text { Effect of feeding systems on meat yield } \\ S_{j}= & \text { Effect of the sex on carcass yield } \\ (M S)_{i k}= & \begin{array}{l}\text { Interaction effect of the } \mathrm{i}^{\text {th }} \text { feeding systems and the } \\ \mathrm{j}^{\text {th }} \text { sex }\end{array} \\ e_{i j k}= & \text { Random error component }\end{array}$

\section{Results and discussion}

\section{The effect of feed on carcass yield}

Effect of feed on carcass characteristics were also significant $(\mathrm{P}<0.05)$ as summarized in (Table 3$)$. Feed significantly $(\mathrm{P}<0.05)$ affected all the parameters measured. The experiment further revealed that cocks showed remarkable and better carcass yield than hens for all the traits measured (Table 3). A two way ANOVA was conducted that examined the effect of feed and sex on meat yield. There was statistically significant difference on live weight, cold dressed weight after de feathered and weight after bleeding of hens and cocks on simple ration followed by those on maize bran then control meaning that feed had an effect on live weight cold dressed weight, weight after de feathered and weight after bleeding. The above results indicate that supplementing the indigenous chickens improves the performance of the chickens in terms of the meat yield as well as growth rate.

Because of its movement, indigenous chickens require more energy in search of the feed, they consume additional energy feed for scavenging activities and stop feeding when the crop and gizzard are filled to capacity (nibbling). ${ }^{8}$ Since village chickens mainly scavenge in order to obtain feed, the scavenging feed resources are not concentrated enough in terms of energy because they do not contain sufficient quantity of starch and they have high fiber content. Cereals have high amounts of crude fiber and cellulose (20-30\%). ${ }^{9}$ According to Theerachai ${ }^{10}$ reported that male normal feathered indigenous chicken cocks had higher proportion of total carcass due to sex differences which arises due to physiological activities where hens involved in egg laying activities which requires high energy and reduce their weights compared to cocks. Furthermore, supplementing village chickens with commercial feed tend to give them intramuscular fat and resulting in better sensory attributes. ${ }^{11}$ Consumers' preferences for village chicken meat is attributed to leanness, flavor and presumed organic origin than broilers (Table 4).

Results in Table 4 showed that there was high significant difference $(\mathrm{P}<0.05)$ of chicken parts on those chickens under simple ration followed by those on maize bran and control meaning that simple ration had an effect on chicken parts. The above means of the thigh, breast muscle, back portion, drum stick and drumstick wing of chickens (cocks) under simple ration were high compared to those means of cocks on the maize bran and control, meaning that simple ration had an effect on chicken parts on cocks the same trend occurred in hens under simple ration, maize bran and control. Meaning that when the local chickens under free range are supplemented with simple ration there is much yield of chicken parts compared to those on the full scavenging and those on maize bran, when the local chickens are supplemented with the feed contain the protein it improves the productivity of the local chickens according to Theerachai. ${ }^{10}$ Rearing chickens with full feed supplements result in village chickens with high percentage of breast muscle, which was tenderer and of a better quality than muscle from an extensive system. ${ }^{11}$

Table 5 indicates the visceral organs and there means, the means of empty gizzards, empty intestines and liver of chickens under simple ration were high compared to those on maize bran and control meaning that simple ration had an effect on the visceral organs and there was high significant difference $(\mathrm{P}<0.05)$ on visceral organs under simple ration followed by those on maize bran and control, because after analysis there was correlation of results of visceral organs under 
maize bran and control $(\mathrm{P}<0.001)$ toward to significant difference. There were much of these correlations because when chickens are supplemented or changed to another feed the gizzard tends to increase in size for digestion of the feed, this is so because gizzard helps grinding the feed. The empty intestines tend to have high weights

Table 3 The effect of feed on carcass yield (mean \pm SE) due to the processes of absorption. Based on literature according to Aderemi ${ }^{12}$ found that the percentage of gizzard of indigenous chicken was higher than in broilers and that this may be due to the work load required to grind the feed particles of different nature available to the birds in scavenging system.

\begin{tabular}{llll}
\hline Parameter & Control & Simple ration & Maize bran \\
\hline Hens & & & \\
Live weight & $998.25 \pm 0.49^{\mathrm{c}}$ & $1297.43 \pm 0.470^{\mathrm{a}}$ & $1099.4 \pm 0.470^{\mathrm{b}}$ \\
Hot dressed wt & $798.38 \pm 0.42^{\mathrm{c}}$ & $1094.39 \pm 0.410^{\mathrm{a}}$ & $899.8 \pm 0.410^{\mathrm{b}}$ \\
Cold dressed wt & $776.13 \pm 0.5^{\mathrm{c}}$ & $1048.57 \pm 0.458^{\mathrm{a}}$ & $881.4 \pm 0.458^{\mathrm{b}}$ \\
After bleeding & $973.75 \pm 1.213^{\mathrm{c}}$ & $1275 \pm .986^{\mathrm{a}}$ & $1077 \pm .973^{\mathrm{b}}$ \\
DE feathered & $948.625 \pm 1.233^{\mathrm{c}}$ & $1250 \pm 1.318^{\mathrm{a}}$ & $1052 \pm 1.560^{\mathrm{b}}$ \\
Cocks & & & \\
Live weight & $999 \pm\left. 0.49\right|^{\mathrm{c}}$ & $1298.8 \pm 0.470^{\mathrm{a}}$ & $1100 \pm 0.470^{\mathrm{b}}$ \\
Hot dressed wt & $801.125 \pm 0.498^{\mathrm{c}}$ & $1098.29 \pm 0.410^{\mathrm{a}}$ & $1060.8 \pm 0.410^{\mathrm{b}}$ \\
Cold dressed wt & $780.125 \pm 0.479^{\mathrm{c}}$ & $1079.57 \pm 0.458^{\mathrm{a}}$ & $899.43 \pm 0.458^{\mathrm{b}}$ \\
After bleeding & $977.750 \pm 0.996^{\mathrm{c}}$ & $1276 \pm 0.953^{\mathrm{a}}$ & $1078 \pm 0.953^{\mathrm{b}}$ \\
De feathered & $954.250 \pm 1.744^{\mathrm{c}}$ & $1251 \pm 1.560^{\mathrm{a}}$ & $1054 \pm 1.318^{\mathrm{b}}$ \\
\hline
\end{tabular}

abc means with different superscript within the rows are significantly different at $\mathrm{P}<0.05$

Table 4 The effect of feed on carcass yield on parts (mean \pm SE)

\begin{tabular}{llll}
\hline Parameter(g) & Control & Simple ration & Maize bran \\
\hline Hens & & & \\
Drumstick & $88.14 \pm 2.828^{\mathrm{b}}$ & $135.142 \pm 2.193^{\mathrm{a}}$ & $96.4 \pm 2.302^{\mathrm{b}}$ \\
Thigh & $99.75 \pm 1.669^{\mathrm{c}}$ & $186.429 \pm 2.370^{\mathrm{a}}$ & $157 \pm 2^{\mathrm{b}}$ \\
Back portion & $126.5 \pm 1.604^{\mathrm{b}}$ & $189.143 \pm 0.469^{\mathrm{a}}$ & $137.4 \pm 1.673^{\mathrm{a}}$ \\
Breast muscle & $128.25 \pm 0.109^{\mathrm{b}}$ & $136.143 \pm 0.206^{\mathrm{a}}$ & $130 \pm 0.668^{\mathrm{b}}$ \\
Drumstick wing & $57.25 \pm 2.375^{\mathrm{b}}$ & $93.286 \pm 0.175^{\mathrm{a}}$ & $68.6 \pm 1.673^{\mathrm{b}}$ \\
Cocks & & & \\
Drumstick & $88.5 \pm 0.691^{\mathrm{b}}$ & $136.14 \pm 0.660^{\mathrm{a}}$ & $96.4 \pm 0.660^{\mathrm{b}}$ \\
Thigh & $100.25 \pm 0.562^{\mathrm{b}}$ & $187.4 \pm 0.538^{\mathrm{a}}$ & $159 \pm 0.538^{\mathrm{a}}$ \\
Back portion & $128.75 \pm 0.957^{\mathrm{b}}$ & $196.8 \pm 0.924^{\mathrm{a}}$ & $138 \pm 1.915^{\mathrm{b}}$ \\
Breast muscle & $155.75 \pm 0.417^{\mathrm{b}}$ & $165.2 \pm 0.417^{\mathrm{b}}$ & $163.57 \pm 0.417^{\mathrm{b}}$ \\
Drumstick wing & $56.2 \pm 1.082^{\mathrm{b}}$ & $98.2 \pm 1.68 \mathrm{I}^{\mathrm{a}}$ & $66.857 \pm 1.681^{\mathrm{b}}$ \\
\hline
\end{tabular}

abc means with different superscript within the rows are significantly different at $\mathrm{P}<0.05$

Table 5 The effect of feed on carcass yield on visceral organs (mean \pm SE)

\begin{tabular}{llll}
\hline Parameter(g) & Control & Simple ration & Maize bran \\
\hline Cocks & & & \\
Empty gizzards & $36.25 \pm 0.98^{\mathrm{b}}$ & $50.6 \pm 0.94^{\mathrm{a}}$ & $38.57 \pm 0.83^{\mathrm{b}}$ \\
Empty intestines & $36.5 \pm .1 .113^{\mathrm{b}}$ & $52.4 \pm 1.065^{\mathrm{a}}$ & $41 \pm .1 .065^{\mathrm{b}}$ \\
Liver & $24 \pm .528^{\mathrm{b}}$ & $26.6 \pm .505^{\mathrm{a}}$ & $25.285 \pm 0.505^{\mathrm{b}}$ \\
Hens & & & \\
Empty gizzards & $35.25 \pm 0.984^{\mathrm{b}}$ & $47.7 I \pm 0.94 \mathrm{I}^{\mathrm{a}}$ & $36.4 \pm 0.94 \mathrm{I}^{\mathrm{b}}$ \\
Empty intestines & $34.625 \pm 1.113^{\mathrm{b}}$ & $50.29 \pm 1.065^{\mathrm{a}}$ & $38.6 \pm 1.065^{\mathrm{b}}$ \\
Liver & $23.125 \pm 0.528^{\mathrm{b}}$ & $26.123 \pm 0.505^{\mathrm{a}}$ & $25.2 \pm 0.505^{\mathrm{b}}$ \\
\hline
\end{tabular}

abc means with different superscript within the rows are significantly different at $\mathrm{P}<0.05$ 


\section{Comparison of meat yield of cocks and hens on different supplements}

After conducting the two way ANOVA to examine the effect of simple ration, maize bran and control on cocks under these treatments, the cocks showed the highest dressing percentage, cold dressing weight, weight after bleeding, weight after de feathered $(\mathrm{P}<0.05)$ compared to cocks on maize bran and control on the same parameters. The same trend occurred on hens under both treatments. According to Theerachai ${ }^{10}$ reported that male normal feathered indigenous chicken cocks had higher proportion of total carcass. But still there was slight difference on hens under simple ration and maize bran in terms of their weights showing that the energy that are stored in the body are used for the movement to search feed for those hens under control but those hens under simple ration and maize bran they had enough energy and the movement in search of feed was limited and the body was able to convert the stored energy into usable resources such as fat, that is why their weights were high compared to those on control. The results indicate that although hens undergo physiological activities such as egg laying, when the feed is available they still maintain their weights since the energy and proteins used during these physiological activities are replaced with the feed supplemented hence the meat yield of hens under scavenging were improved. Stocking density is an important factor that governs the birds' ability to exercise and this has an effect on the bird's energy utilization.

The low stocking density under outdoor production systems increases the birds' ability to exercise through exhibiting natural behaviors like walking, scratching and wing flapping. ${ }^{13}$ These activities favor myogenesis instead of lipogenesis ${ }^{14}$ because protein synthesis is stimulated by the increased activity. ${ }^{15}$ Based on results findings in this experiment indicates that when cocks and hens are supplemented with feed containing protein and energy will improve the meat yield and quality of meat. To have more yield in local cocks and hens farmers need to do supplementation using complete feed doing this will help them to get more profit.

\section{Comparison of meat yield of parts between the cocks among different supplements}

After conducting the two way ANOVA to examine the feed supplementation on chicken parts of cocks, it indicates that drumstick, thigh, back portion, breast muscle and drumstick wing under simple ration were high compared to those on maize bran and control meaning that simple ration had an effect on chicken parts of cocks and there was high significant difference $(\mathrm{P}<0.05)$ compared to those on maize bran and control. The same trend occurred in hens under both treatments. Chickens under scavenging conditions they stimulates a hypertrophic muscular growth of thigh and breast muscle that's according to Dransfield et al. ${ }^{15}$ The results are similar with the findings of Castellini et al. ${ }^{14}$ who reported that the breast meat increased when birds were managed at a lower stocking density in outdoor management systems. Since birds under scavenging conditions are more adapted to stress conditions than the confined counterparts, this could reduce preslaughter stress thus conserving more glycogen in the muscles. Meat with a lower ultimate $\mathrm{pH}$ has been reported to have a longer shelf life because low $\mathrm{pH}$ increases the lag phase time of psychrotrophic bacteria that are known to spoil meat ${ }^{16,17}$ (Table 6).

The two way ANOVA showed that there was correlation of results of empty gizzard, liver, and empty intestines of those cocks under simple ration and maize bran at significant level of $\mathrm{P}<0.05$ and there means were high meaning that simple ration and maize bran had an effect on visceral organs. The same trend occurred in visceral organs of hens. According to Aderemi ${ }^{12}$ found that the percentage of gizzard of indigenous chicken was higher than in broilers and that this may be due to the work load required to grind the feed particles of different nature available to the birds in scavenging system and Tamilvanan ${ }^{18}$ reported that the weight of liver of indigenous chickens was higher than in broilers which could be due to increased metabolic activities in an effort to make up for the reduced availability of protein as the indigenous chickens are reared in free range system (Table 7).

Table 6 Comparison of visceral organs of cocks and hens on different supplements (means \pm SE)

\begin{tabular}{llll} 
Parameter(g) & Control & Simple ration & Maize bran \\
\hline Cocks & & & \\
Empty gizzards & $36.25 \pm 0.98^{\mathrm{b}}$ & $50.6 \pm 0.94^{\mathrm{a}}$ & $38.57 \pm 0.83^{\mathrm{b}}$ \\
Empty intestines & $36.5 \pm .1 .113^{\mathrm{b}}$ & $52.4 \pm 1.065^{\mathrm{a}}$ & $41 \pm .1 .065^{\mathrm{b}}$ \\
Liver & $24 \pm .528^{\mathrm{b}}$ & $26.6 \pm .505^{\mathrm{a}}$ & $25.285 \pm 0.505^{\mathrm{b}}$ \\
Hens & & & \\
Empty gizzards & $35.25 \pm 0.984^{\mathrm{b}}$ & $47.71 \pm 0.94 \mathrm{I}^{\mathrm{a}}$ & $36.4 \pm 0.94 \mathrm{I}^{\mathrm{b}}$ \\
Empty intestines & $34.625 \pm 1.113^{\mathrm{b}}$ & $50.29 \pm 1.065^{\mathrm{a}}$ & $38.6 \pm 1.065^{\mathrm{b}}$ \\
Liver & $23.125 \pm 0.528^{\mathrm{b}}$ & $26.123 \pm 0.505^{\mathrm{a}}$ & $25.2 \pm 0.505^{\mathrm{b}}$ \\
\hline
\end{tabular}

abc means with different superscript within the rows are significantly different at $\mathrm{P}<0.05$

Table 7 Interaction of feeding and sex on carcass yield characteristics (Mean $\pm \mathrm{SE})$

\begin{tabular}{|c|c|c|c|c|}
\hline Parameter(g) & Feeding & Sex & Mean( \pm SE) & SIG \\
\hline \multirow{6}{*}{ Live weight } & \multirow{2}{*}{ Control } & Male & $999 \pm .491$ & \multirow{6}{*}{$*$} \\
\hline & & Female & $998.25 \pm .49 \mid$ & \\
\hline & Simplo ntion & Male & $1298.8 \pm .470$ & \\
\hline & Simple ration & Female & $1194 \pm .462$ & \\
\hline & \multirow{2}{*}{ Maize bran } & Male & $1100 \pm .470$ & \\
\hline & & Female & $1099.4 \pm 429$ & \\
\hline \multirow{6}{*}{ Hot carcass } & \multirow{2}{*}{ Control } & Male & $798.5 \pm .429$ & \multirow{6}{*}{$*$} \\
\hline & & Female & $780.125 \pm .429$ & \\
\hline & Simo ration & Male & $1098.236 \pm .410$ & \\
\hline & & Female & $1092.286 \pm .515$ & \\
\hline & \multirow{2}{*}{ Maize bran } & Male & $899.429 \pm .410$ & \\
\hline & & Female & $879.8 \pm .390$ & \\
\hline \multirow{6}{*}{ Cold carcass } & \multirow{2}{*}{ Control } & Male & $781.29 \pm .479$ & \multirow{6}{*}{$*$} \\
\hline & & Female & $780.125 \pm .429$ & \\
\hline & Simontion & Male & $1079.4 \pm 1.949$ & \\
\hline & & Female & $1070.57 \pm .458$ & \\
\hline & \multirow{2}{*}{ Maize bran } & Male & $881.57 \pm .458$ & \\
\hline & & Female & $879.4 \pm 458$ & \\
\hline
\end{tabular}


Table Continued

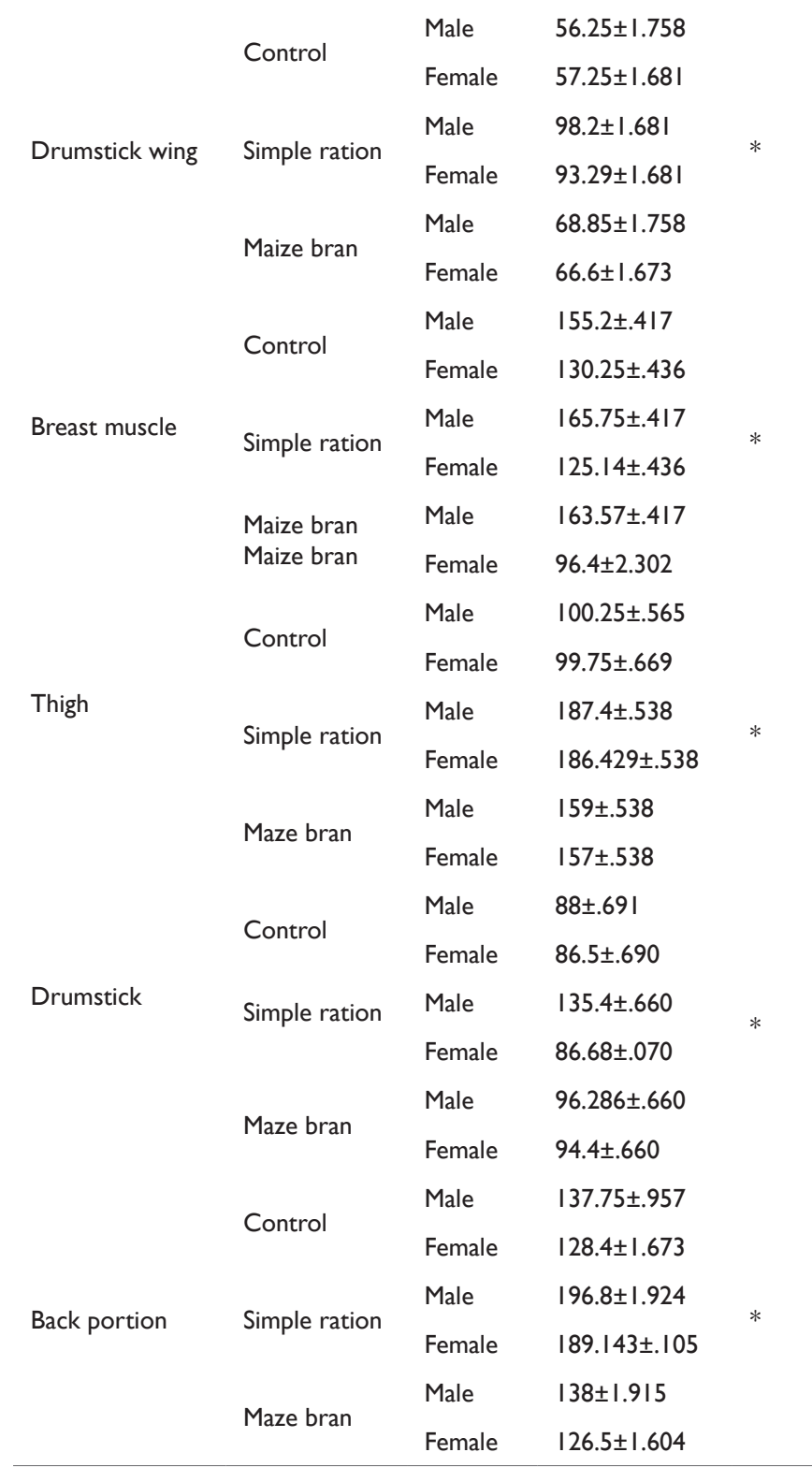

**=Very significant, $*=$ significant, NS=Not significant

A two way ANOVA was conducted that examined the effect of sex and feed on meat yield. There was a statistically significant interaction between the effect of sex and feed on meat yield $\mathrm{P}<0.05$ level. Consistently higher weights found in various carcass parameters in normal feathered males of Malawian chickens than in normal females is consistent with Isidahomen et al. ${ }^{19}$ who found similar results in Nigerian indigenous chickens reared under both free range and intensive systems. It has also been reported that sex differences were usually due to differences in hormonal profile, aggressiveness and dominance especially when both sexes are reared together. ${ }^{20}$ In their report, Adedeji et al. ${ }^{21}$ stated that the aggressiveness of males over the females especially when reared together put the females at a disadvantage for feed and water. According to Musa et al. ${ }^{22}$ growth and carcass differences between cocks and hens were due to differences in feed metabolism and in the onset of fattening. From the results it shows that the cocks that were on simple ration and maize bran had more meat yield and better quality compared to females on both feeding systems but those hens under complete feed had more yield compared to the cocks on control.

\section{Conclusion}

Supplementing indigenous chickens under scavenging conditions with simple ration (Soybean meal, maize bran and salt) result in more carcass and organs yield. It was also observed that cocks had higher carcass and organ yield compared to hens in all the treatments. Therefore farmers should be supplementing indigenous chickens by formulating simple ration ( $89 \%$ maize bran, $10.75 \%$ soybean meal and $0.25 \%$ salt).

\section{Acknowledgements}

The authors sincere give thanks to entire team of InCIP for their support and provision of resources used during research period, $\mathrm{Mr}$. D Chiumia, Miss Mtisunge Chinunda, Mr.F Chimwendo for their assistance and advice; Prof .TN Gondwe and Dr.W. Jere for assisting in the data analysis and all members of staff in the Animal Science Department at Bunda campus.

\section{Conflict of interest}

Authors declare that there are no conflicts of interest.

\section{References}

1. Goromela EH, Kwakel RP, Verstegen MAA, et al. Strategies to optimize the use of scavengeable feed resource base by smallholders in traditional poultry production systems in Africa: A review. African Journal of Agricultural Research. 2006;1(3):91-100.

2. Gichohi CM, Maina JG. Poultry production and marketing. Ministry of Livestock Production. Kenya: Paper presented in Nairobi; 1992:23-27.

3. Gondwe TN, Wollny CBA. Evaluation of the Growth Potential of Local Chickens in Malawi. International Journal of Poultry Science. 2005;4(2):1-7.

4. Mwalusanya NA, Katule AM, Mutayoba SK. Nutrient status of crop contents of rural scavenging local chickens in Tanzania. Br J Poultry Sci. 2002;43(1):64-69

5. Ologhobo AD. The dilemma of animal feeds and indigenous poultry in Nigeria. Proceedings of $19^{\text {th }}$ World's Poultry congress, Amsterdam. 1992;(2):81-86.

6. Gunaratne SP, Chandrasir A, Halamatha W. Feed resource base for scavenging village chickens in Sri Lanka. Trop Anim Health Prod. 1993;25(4):249-257

7. Tadele D. Studies on village poultry production systems in the Central Highlands of Ethiopia MSc Thesis. Sweden: Swedish University of Agricultural Sciences; 1996.

8. Minh DV. Effect of Supplementation, Breed, Sea-son and Location on Feed Intake and Performance of Scavenging Chickens in Vietnam. In: Petrus NP, editor. Acta universitatis agriculturae sueciae; 2005.

9. Kondombo SR, Nianogo AJ, Kwakkel RP. Comparative analysis in village chicken production in two farming systems in Burkina Faso. Trop Anim Health Prod. 2003;35(5):563-574.

10. Theerachai H. Study on chicken meat production for small scale Farmers in North east Thailand. Germany: kassel university press; 2006. 
11. Watanachant C, Watanasit S, Watanachant S. Carcass Characteristics, physical property and chemical composition of naked-neck and Thai indigenous chickens reared under backyard production systems. 2007.

12. Aderemi FA. Rural poultry production in western middle-belt region of Nigeria Proceeding of the $8^{\text {th }}$ Annual Conference of AS Association of Nigeria, Miuna. 2003;25-27.

13. Dal Bosco A, Mugnai C, Sirri F. Assessment of a Global Positioning System to Evaluate Activities of Organic Chickens at suture. Journal Applied to Poultry Resources. 2010;19:213-218.

14. Castellini C, Mugnai C, Dal Bosco A. Meat Quality of Three Chicken Genotypes Reared According to the Organic System. Italian Journal of Food Science. 2002;14(4):401-412.

15. Dransfield E, Sosnicki AA. Relationship between muscle growth and poultry meat quality. Poult Sci. 1999;78(5):743-746.

16. Pietrzak M, Greaser ML, Sosnicki AA. Effect of Rapid Rigor Mortis processes on Protein Functionality in Pectoralis major Muscle of Domestic Turkeys. J Anim Sci. 1997;75(8):2106-2116.
17. Allen MJ, Drummond JA, Moffat KG. Analysis of two P-element enhancer-trap insertion lines that show expression in the giant fibre neuron of Drosophila melanogaster. Genes Brain Behav. 2007;6(4):347358 .

18. Tamilvanan T. Carcass yield and quality characters of brolier chicken under cage and floor management systems fed with different processed feed and probiotics. Indian Vet J. 2003;(80):152-155.

19. Isidahomen CE, Ilori BM, Akano K. Genetic and Sex Differences in Carcass Traits of Nigerian Indigenous Chickens. Journal of Animal Science Advances. 2012;2(7):637-648.

20. Ilori BM, Peters SO, Ikeobi CON, et al. Comparative Assessment of Growth in Pure and Crossbred Turkeys in a Humid Tropical Environment. International Journal of Poultry Science. 2010;9(4):368-375.

21. Adedeji TA, Adebambo OA, Ozoje MO. Early growth performance of crossbred chickens resulting from different sire strains. 2004.

22. Musa HH, Chen GH, Cheng JH. Study on carcass characteristics of chicken breeds raised under the intensive condition. International Journal of Poultry Science. 2006;5(6):530-533. 